\title{
In Partnership with The Global Award for Entrepreneurship Research
}

\author{
Zoltan Acs · David B. Audretsch
}

Accepted: 28 May 2009/Published online: 26 June 2009

(C) The Author(s) 2009. This article is published with open access at Springerlink.com

As Editors-In-Chief of Small Business Economics Journal (SBEJ), we are happy to announce that the journal and Springer Publishing have entered into an agreement with the three organizations behind "The Global Award for Entrepreneurship Research": the Swedish Entrepreneurship Forum (formerly FSF), the Research Institute of Industrial Economics (IFN), and the Swedish Agency for Economic and Regional Growth. As a result of this agreement, we now formally have the honor of publishing an expert evaluation of the award winner's contribution to entrepreneurship research as well as the award lecture given by the winner upon receipt of the prize.

Since 2003, SBEJ has been proud to publish the award lectures of winners of the "International Award for Entrepreneurship and Small Business Research", which is known colloquially as "The FSF-NUTEK Award", and the evaluations of these lectures. With the recent upgrading of the award, the existing agreement has been formalized.

The formal cooperation was initiated in the January 2009 issue of SBEJ with Magnus Henrekson and Anders Lundström's article on "The Global Award for Entrepreneurship Research", which not only served to introduce the new award and its rules and regulations for the nomination, evaluation, and

Z. Acs - D. B. Audretsch $(\square)$

Max Planck Institute of Economics, Kahlaische Straße 10, 07745 Jena, Germany

e-mail: sbejmeditor@gmail.com selection of winners, but also presented a retrospective look at previous winners.

The first winner of new "Global Award for Entrepreneurship Research" was announced on January 29, 2009: Professor Scott A. Shane of Case Western Reserve University in Cleveland, Ohio.

With this issue of SBEJ we are pleased to publish the first set of papers related to the new award. Per Davidsson and Johan Wiklund have provided an excellent evaluation of Scott Shane's contributions to entrepreneurship research in their article "Scott A. Shane: winner of the Global Award for Entrepreneurship Research". Scott A. Shane's prize lecture, "Why encouraging more people to become entrepreneurs is bad public policy", which was presented at the award ceremony in Stockholm on May 14, 2009, is published immediately following the evaluation.

As Editors of SBEJ we are convinced that deepening our insights into the conditions, characteristics, drivers, and effects of entrepreneurship and formulating policy recommendations are of immense value. Thus, within the context that the "Global Award for Entrepreneurship Research" facilitates the dissemination of research results to scholars, practitioners, and individuals/groups involved in small business development, considerable good will be achieved with the publication of the award lecture and an expert evaluation of this lecture. At the same time, the publication of the prize lecture and an evaluation of this lecture by experts will provide a 
source of inspiration for entrepreneurship scholars around the world.

Partnership with the "Global Award for Entrepreneurship Research" is an honor. When the Small Business Economics Journal was established in 1989, the role of small business owners and other entrepreneurs was not understood. The crucial role of the entrepreneur as a source of innovation and job creation is now clearly understood, in part due to research published in this very journal. We are proud that SBEJ is on the frontiers of entrepreneurship research, promoting excellence in research and being a leading source of information to scholars.

Open Access This article is distributed under the terms of the Creative Commons Attribution Noncommercial License which permits any noncommercial use, distribution, and reproduction in any medium, provided the original author(s) and source are credited. 